\title{
A descriptive study on English language anxiety amongst General Nursing and Midwifery students
}

\author{
Jaspreet Kaur $^{1}$ \\ ${ }^{1}$ Assistant Professor, Desh Bhagat University School of Nursing, Punjab. \\ E-mail-kjaspreet88@yahoo.in
}

\begin{abstract}
Background : Learning English is a pre-requisite to be able to successfully participate in many academic and cultural activities, trade, technology and worldwide communication. Therefore, English has become one of the most important subjects in the educational system. However, it has been observed that many students experience anxiety while trying to learn English. The present study was conducted to assess English Language Anxiety among the General Nursing \& Midwifery students.

Methodology : A sample of 200 subjects was drawn by simple random sampling technique. One to one interview method was used to collect the data by using Modified Foreign Language Classroom Anxiety Scale (FLCAS). The data was subjected to computerized statistical analysis.

Results : The present study revealed that majority $144(72.5 \%)$ of students reported moderate anxiety followed by $49(24.5 \%)$ of students that reported low anxiety and only $6(3.5 \%)$ of students reported high anxiety related to English language. Further, it was found that majority $(46.3 \%)$ of students reported anxiety in writing English, (45.3\%) of students reported anxiety in speaking English, (42.2\%) of students reported anxiety in grammar and equal (41.2\%) of students reported anxiety in listening to English conversations and reading English.

Conclusion: Thus, majority of students reported moderate level of anxiety. Teachers should have learning activities where these students are given guidance on how to talk or write in English. In addition, teachers should also try to create a non-threatening, relaxed learning environment in which students can make mistakes while learning English without fear of embarrassment.
\end{abstract}

Keywords : Anxiety, English Language Anxiety, Foreign Language Classroom Anxiety Scale (FLCAS).

\section{INTRODUCTION}

Anxiety is a part of everyday life. It is ubiquitous in humans, and its presents in a range of anxiety disorders making it an important clinical focus. Learning English is a pre-requisite to being able to successfully participate in many academic and cultural activities, trade, technology and worldwide communication. Therefore, English has become one of the most important subjects in the educational system. However, it has been observed that many students experience anxiety while trying to learn English [1]. English language being foreign language is introduced as a second language in India and poses many problems to the learners who are new to it. Children face difficulties in learning the pronunciation, sentence structure, grammar, vocabulary and other aspects of the English language. Many studies have found that the college students, who were more anxious, received significantly lower final grades than less anxious students [2]. The teachers of English or the enthusiastic researchers should take initiative to take some remarkable work in this field and should introduce innovative practices in teaching English language in an effective manner [3]. Students who are proficient in English will have better chances of employment after they have graduated. It is so as employers do not simply look at their 
excellent academic results but also their proficiency in the second language. Companies nowadays do not only select the best graduates who can deliver technical skills but also those that possess soft skills [4]. These soft skills include the ability to communicate in English effectively and job interviews are now conducted in English. Thus, confidence in spoken English is very important to graduates as it proves that they are the suitable candidate for the job [5].

\section{METHODOLOGY}

A descriptive research design was adopted to assess the English language anxiety among General Nursing and Midwifery (GNM) students at selected nursing Institute of district Fatehgarh sahib, Punjab. The total of 200 General Nursing and Midwifery (GNM) students were selected by using Simple random Sampling Technique. Modified Foreign Language anxiety Scale (FLAS) was used which was validated from experts. The reliability of tool was determined by test-retest method by using Karl Pearson's coefficient of correlation which was found to be reliable as $r$ value was 0.82 [6]. The collected data was analyzed by descriptive statistics.

\section{RESULTS}

In relation to age most of students $89(44.5 \%)$ were between $21-23$ year of age followed by $18-20$ years of age $80(40 \%)$ and $24-26$ year of age $31(15.5 \%)$. In relation to gender, majority of students were female $121(60.5 \%)$ followed by males students $79(39.5 \%)$. In relation to residential area, most were from rural areas $113(56.5 \%)$ followed by urban area $87(43.5 \%)$. Majority 144 $(72.5 \%)$ of students reported moderate anxiety followed by $49(24.5 \%)$ of students reported low anxiety and only $6(3.5 \%)$ of students reported high anxiety related to English language among GNM students. Hence it can be concluded that most of the students reported moderate anxiety related to English language (Table 1). It was found that majority (46.3\%) of students reported anxiety in writing English, (45.3\%) of students reported anxiety in speaking English, (42.2\%) of students reported anxiety in grammar and equal (41.2\%) of students reported anxiety in Listening and Reading English. Thus, it can be concluded that majority of GNM students reported anxiety in writing English (Table 2).

Table 1

Frequency and Percentage Distribution of level of Anxiety related to English language among GNM Students

\begin{tabular}{|ccc|} 
& & $\mathrm{N}=200$ \\
\hline Level of Anxiety (Score Range) & Frequency (f) & Percentage (\%) \\
\hline High Anxiety (27-40) & 7 & 3.5 \\
Moderate Anxiety (14-26) & 144 & 72.5 \\
Low Anxiety (0-13) & 49 & 24.5 \\
\hline
\end{tabular}

Table 2

Dimension wise Comparison of level of Anxiety related to English language among GNM Students.

$$
\mathrm{N}=200
$$

\begin{tabular}{|ccccc|} 
Sr. No & Dimensions & Mean & SD & Mean \% \\
\hline 1. & Speaking & 3.63 & 1.52 & $45.3 \%$ \\
2. & Listening & 3.29 & 1.53 & $41.2 \%$ \\
3. & Reading & 3.32 & 1.55 & $41.5 \%$ \\
4. & Writing & 3.70 & 1.77 & $46.2 \%$ \\
5. & Grammar & 3.38 & 1.58 & $42.2 \%$ \\
\hline
\end{tabular}




\section{DISCUSSION}

The present study revealed that majority of students had reported moderate English language anxiety. Similar findings were reported in another study [7] where students had moderate level of English language anxiety. Other studies in nursing students have reported that students experienced moderate English language anxiety [8]. The results of present study also revealed that majority of students reported English language anxiety in writing. Similarly, a study on English language anxiety in relation to language skills and found that students had more negative evaluation towards writing in English than in other skills [9]. A number of confounding variables were not addressed in the study which can be taken up as a limitation of the study. The study also emphasizes the need for nursing students to learn English while suggesting than non stressful methods of learning be employed to do so.

\section{REFERENCES}

1. Deepak K, Patel D, Prajapati P, Saini K. Level of Anxiety related to English Language among General Nursing and Midwifery students. Indian Journal of Psychiatric Nursing 2014;8(1):23-5.

2. Hemamalini HC. English Language Anxiety In Relation To English Achievement Among The High School Students. The Modern Language Journal 2012;4:90-110.

3. Gaibani AA. Determining the Role Of English Language Competence in Influencing the Public Speaking Anxiety of International Post Graduate Students at the University of Utara, Malaysia. Int J Learn Dev 2014;4(2):111-9.

4. Suliman WA, Halabi J. Critical thinking, self-esteem, and state anxiety of nursing students. Nurs Educ Today 2007;27(2):162-8.

5. Horwitz EK. Preliminary evidence for the reliability and validity of a foreign language anxiety scale. Tesol Quart 1986;20(3):559-62.

6. Lian LH, Budin MB. Investigating the relationship between English Language Anxiety and the Achievement of School based oral English Test among Malaysian form four students. Int J Learn Teach Educ Res 2014;2: 167-70.

7. Horwitz EK, Young DJ. Language anxiety: From theory and research to classroom implications. Pearson College Division : USA ; 1991

8. Mary Angela Olson MA BS. English-as-a-second language (ESL) nursing student success: A critical review of the literature. J Cult Divers 2012;19(1):26-32.

9. Sila AY. Young Adolescent Students' Foreign Language Anxiety in Relation to Language Skills at Different Levels. J Int Social Res 2010;3:86-9.

$$
\begin{aligned}
& \text { Acknowledgements - Nil } \\
& \text { Source of Funding - Nil } \\
& \text { Conflict of Interest - Nil }
\end{aligned}
$$

